\title{
Belgeo
}

Revue belge de géographie

4 | 2018

Transformations of urban space after the fall of

Socialism

\section{Editorial: In search of the post-socialist urban geography. How do we see the post-socialist city today?}

Mikhail Ilchenko and Diana Dushkova

\section{(2) OpenEdition}

\section{Journals}

Electronic version

URL: http://journals.openedition.org/belgeo/31467

DOI: 10.4000/belgeo.31467

ISSN: 2294-9135

Publisher:

National Committee of Geography of Belgium, Société Royale Belge de Géographie

Electronic reference

Mikhail Ilchenko and Diana Dushkova, « Editorial: In search of the post-socialist urban geography. How do we see the post-socialist city today? », Belgeo [Online], 4 | 2018, Online since 23 January 2019, connection on 12 October 2020. URL : http://journals.openedition.org/belgeo/31467 ; DOI : https:// doi.org/10.4000/belgeo.31467

This text was automatically generated on 12 October 2020

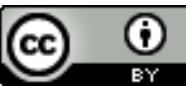

Belgeo est mis à disposition selon les termes de la licence Creative Commons Attribution 4.0 International. 


\title{
Editorial: In search of the post- socialist urban geography. How do we see the post-socialist city today?
}

\author{
Mikhail Ilchenko and Diana Dushkova
}

1 Today the question of the future development of post-socialist cities is increasingly attracting attention of researchers. The past few years alone saw a plethora of major academic publications and special issues, as well as many conferences and workshops (see e.g. Brade, Neugebauer, 2017; Ferenčunhová, Gentile, 2016; Gentile, 2018; Frost, 2017; Hagen, Diener, 2018). This is understandable. Three decades has passed since the collapse of the socialist system - a long enough period to provide some answers to the main question: does post-socialist city actually exist?

2 If we proceed from the assumption that the post-socialist cities follow the logic of transition from their existence as "socialist" cities towards the market, democracy and global communication system (Sýkora, Bouzarovski, 2012; Kovács, 2000; Andrusz, Harloe \& Szelenyi, 1996), then the logical conclusion is that the very subject of this research - the post-socialist city itself - should eventually disappear. That is, the "socialist" city either should have already become subsumed into the new reality, or it should be well on its way out.

Of course, such an approach does not imply that the research subject itself has to disappear. On the contrary, it poses a variety of questions: how to determine what "transitional" phase a city goes through, in which ways the cities overcome their socialist past, what obstacles they face, how fast they adopt the new practices and so on. All of these themes are important and deserve deeper consideration. However, it is equally important to remember that within this framework the concept of "postsocialist city" becomes little more than a metaphor applied to a temporary situation. The prefix "post" serves as a veil obscuring the range of questions and challenges that, for various reasons, have become common for a number of neighboring countries at a certain historical period (Dmitrieva, Kliems, 2010; Stenning, Hörschelmann, 2008). As a result, the concept of a "post-socialist" city becomes a "container term" used to 
describe heterogeneous phenomena (Hirt, Ferenčunhová \& Tuvikene, 2016; Hirt, 2013; Tuvikene, Sgibnev \& Neugebauer, 2019). What do post-socialist cities have in common? Their common past and the inevitable need to overcome it. Therefore, the use of this research framework focuses the researchers' attention on the need to discern the "remnants" of this past and to determine how fast or how successfully these remnants disappear.

4 If this is the case, can we talk about post-socialist urban geography as a distinctive phenomenon? Perhaps we can, but only as a temporary stage; and more in a territorial and physical sense than in a social or cultural one. Indeed, even if the post-socialist cities managed to develop some common social or economic features over the past decades, the logic of "transition" inevitably makes us perceive such features as transitory and temporary. They may deserve our attention, but they are doomed to be seen as "side effects", obstacles hindering the process of shaking off the "difficult socialist legacy" (Bouzarovski, Sýkora \& Matoušek, 2016).

5 However, it is also possible to approach the post-socialist "transition" through a different perspective. What if all the "temporary", "hybrid", "transitional" phenomena that have emerged within the former socialist cities, metropolises and agglomerations over the past twenty years can be better described not as anomalies or divergences from the norm, but rather as genuine, authentic and sustainable modes of existence? What if they will continue to define the future of post-socialist cities for decades to come? What if the "socialist legacy" will never be completely overcome? Can it ever be completely overcome? For example, how should we proceed with the urban layouts and structures established during the socialist era? of course, the arrival of capital and market has significantly transformed Eastern European cities. Spontaneous development, various land use transformations, new shopping centers, emerging neighborhoods: all of this has profoundly changed the cities' look, their functionality and the way they are perceived. But did these transformations completely obliterate the socialist legacy?

Looking more closely, we can see that the "past" continues to survive within the postsocialist cities, and its presence is much more vital than may initially seem: it survives in the city's appearance, in its building structures, in the very logic of urban development, and in the everyday practices. Even when the socialist legacy is being actively transformed, such transformation leads not to the overcoming of the past but rather to its continuing existence in new capacity (see e.g. Coudroy de Lille, Guest, 2010). This past that is supposedly "changing", "transforming" or "disappearing" still remains intrinsic almost to every part of modern urban existence. This is the conclusion that the papers collected in this issue convincingly and forcefully demonstrate.

7 For example, the past still determines the housing policy standards, the layouts of new developments, the shapes of green spaces, as well as religious practices, local identities, cultural imagery and many more. This socialist past is so ubiquitous within the modern cities that it forces us to an obvious conclusion: the multi-faceted, changing and transforming past is an inherent and inevitable component of the modern post-socialist city (Czepczyński, 2010; Dmitrieva, Kliems, 2010; Tuvikene, Sgibnev \& Neugebauer, 2019). All these hybrid forms, configurations and transitional practices determine its identity and will most likely continue to do so for a very long time, through dynamics, changes, conflicts, tensions and other features of urban existence. To understand a 
post-socialist city means to accept it as it is. Such an acceptance does not necessarily require that we develop new research tools: rather, it challenges us to find a new way of seeing the subject itself.

8 Today the studies of post-socialist cities face several conceptual challenges that researchers, regardless of their approaches and tools, are finding increasingly difficult to ignore. This point is abundantly demonstrated by the papers presented in this issue, with their wide range of topics, themes, narratives and methods.

9 First, the study of post-socialist cities today is hardly possible without an interdisciplinary framework. This means not only that the analysis of urban processes requires interdisciplinary methodology and the range of approaches. The issue boils down to the fact that we cannot even properly think the majority of tendencies and processes that determine the current development of post-socialist cities within any single field or discipline. "Economic", "social" and "cultural" constituents of urban change preserve their value as conceptual generalizations. But can we strictly follow these disciplinary boundaries while, for example, explaining segregation processes, or studying the emergence of new residential practices, or analysing urban public spaces (see e.g. Hirt, 2012)? Can we explore such topics without taking into account the socialist planning structures, the developers' business practices or, for example, the emergence of new local identities? Obviously, the answer is no. Therefore, these field of study always requires a broader context of interpretation, even when engaged with the most narrow and concrete subjects - it presupposes the need for multidisciplinary approach.

Second, it is important to take into consideration the fluidity and openness of the concept of "post-socialist city". In this case the prefix "post" posits questions and delineates the problems rather than offers the solutions. The label of "post-socialist city" captures so many heterogeneous phenomena, processes and conflicts unfolding within the widely diverse spheres of urban life, that any conceptual generalization or normativity is bound to produce serious theoretical difficulties (Gentile, 2018; Hirt, Ferenčunhová \& Tuvikene, 2016; Hirt, 2013; Haase, Rink \& Grossmann, 2016; Haase et al., 2018). Therefore, the researchers relying on this term have to employ critical reflection and proper conceptual appraisal.

11 Third, three decades is a long enough period for the processes of post-socialist urban development to become interpreted and studied from a global perspective: not only by comparing it to an external standard of urban development, but as an integral component of global context, capable of creating and determining its own trends and its own agenda. Or, to put it differently, it is important that we explore the postsocialist city not only in terms of how well it follows the global trends, but also to what extent it shapes these trends. Such an angle has recently inspired intense theoretical discussions among a number of researchers (Müller, 2018; Müller, 2019; Trubina, 2018; Ferenčunhová, Gentile, 2016). This is also the perspective presented, overtly or implicitly, in the articles published in this issue. It is entirely possible that this is the analytical logic that will dominate the post-socialist urban studies in the foreseeable future.

12 Contributions of this issue represent a vast panorama of the disciplines, approaches and research traditions. And perhaps, this is the best evidence that the post-socialist city as a research subject is becoming increasingly more flexible and open, as well as controversial and complicated. 

transformation of the socialist past and its incorporation into the current urban mosaic of meanings, sings and ideological manifestations. Mitin works with the concept of "palimpsest" in order to understand the changes of urban cultural landscapes of the post-socialist cities, relying on the case of the distant residential areas in Moscow. Amiot traces symbolic changes of urban space in Skopje, trying to show how the city's iconography can be reshaped through rewriting the national history and recoding the symbols of socialist heritage.

14 Several contributions are focused on the issues of housing policy and different aspects of the housing markets which demonstrated very special way of development in postsocialist cities as a result of radical changes of spatial urban structures. Bohdan Jałowiecki analyzes controversies and challenges of space privatization and social polarization in Polish cities. Aurore Meyfroidt and Lydia Coudroy de Lille explore the evolution of housing cooperatives in Poland and Slovakia under conditions of neoliberal post-socialist policy. Alain Jarne considers the outcome of the spatial urban transformations in Albania, outlining the main challenges which the country currently faces in terms of the ongoing urbanization tendencies.

15 A separate set of articles is devoted to more traditional questions of geographical studies, making a special accent on the problems of sustainable development, ecological challenges and green infrastructure. The articles by Diana Dushkova and Tatyana Krasovskaya and by Yvette Vaguet address the issues of the northern cities. Dushkova \& Krasovskaya analyze the case of Kirovsk as a typical single-industry northern Russian city which faces a number of serious economic, social and ecological problems on the way to sustainability. Vaguet focuses on the example of the oil and gas towns situated in the Arctic and subarctic zone of the plain of the Ob river and explores their transformations as frontier towns. Contributions prepared by Oxana Klimanova, Eugeny Kolbowsky and Olga Illarionova, and by Alla Pakina together with Aiman Batkalova touch the problem of the green urban areas and their development in large post-socialist metropolises. Klimanova, Kolbowsky \& Illarionova examine the role of the green infrastructure and ecosystem services in the urban transformation of Moscow during the last 25 years. Pakina \& Batkalova attempt to reveal the role and function of the green urban areas in today's spatial development of Almaty city. The article of Gabor Tolnai raises an issue of the waterfront regeneration in post-socialist city drawing on the example of Budapest.

Finally, several authors turn to the issues of various kinds of social interactions and everyday practices established in the post-socialist urban environment. Simona Balčaité and Dovile Krupickaite explore the phenomena of so-called gated communities in Lithuania, paying a special attention on how they can impact a population outside such settlements. Polina Golovátina-Mora, Ekaterina Zelenskaia, Varvara Golovatina \& Piotr Celinski undertake a comparative overview of civic participation practices, analysing different cases of participatory urbanism in three cities of three countries: Poland (Lublin), Czech Republic (Pilsen), and Russia (Yekaterinburg). Márton Berki \& Brigitta Sivadó evaluate the role of religious practices and their reproduction in the cities which were found as exemplary socialist settlements in Hungary in the beginning of 1950 s. Aurore Navarro suggests a thorough analysis of the renovation in the offer of the artisanal food retail in Prague for the recent decade. 
ently that variety of such topics and issues put together under the common label of "post-socialist urban geography" can raise no less questions than give clear answers on the subject. But at the same time, paradoxically, this is the only way to get at least some answers. Since if the post-socialist urban geography really exists, it exists just in this diversity of symbolic, economic, ecological, civic, housing, spatial and many other practices and attitudes. For that reason, we hope that this collection of papers will help if not to find any clear contours of this geography, then at least allow to contribute to better understanding of all those processes and tendencies which take place in the space we used to call "post-socialist".

\section{BIBLIOGRAPHY}

ANDRUSZ, HARLOE \& SZELENYI (1996), Cities After Socialism: Urban and Regional Change and Conflict in Post-Socialist Societies, Wiley-Blackwell.

BOUZAROVSKI S., SÝKORA L. \& MATOUŠEK R. (2016), “Locked-in Post-socialism: Rolling PastDependencies in Liberec's District Heating System”, Eurasian Geography and Economics, 57, 4-5, pp. 624-642.

BRADE I., NEUGEBAUER C.S. (eds.) (2017), Urban Eurasia: Cities in Transformation, DOM Publishers. COUDROY DE LILLE L., GUEST M. (2010), “Towards banalization? Trans-forming the Legacies of Post-Socialist Cities", in DMITRIEVA M., KLIEMS A. (eds.), The Post-Socialist City. Continuity and Change in Urban Space and Imagery, Jovis, pp. 34-51.

CZEPCZYŃSKI M. (2010), “Representations and Images of 'Recent History': the Transition of PostSocialists Landscape Icons”, in DMITRIEVA M., KLIEMS A. (eds.), The Post-Socialist City. Continuity and Change in Urban Space and Imagery, Jovis, pp. 16-33.

DMITRIEVA M., KLIEMS A. (2010), "Introduction: the Post-Socialist City", in DMITRIEVA M., KLIEMS A. (eds.), The Post-Socialist City. Continuity and Change in Urban Space and Imagery, Jovis, pp. 6-15.

FERENČUHOVÁ S., GENTILE M. (2016), “Introduction: post-socialist cities and urban theory”, Eurasian Geography and Economics, 57, 4-5, pp. 483-496.

FROST I. (2017), "Exploring varieties of (post)Soviet urbanization: reconciling the general and particular in post-socialist urban studies”, Europa Regional, 25, 2, 2017 (2018), pp. 2-14.

GENTILE M. (2018), “Three Metals and the 'Post-Socialist City': Reclaiming the Peripheries of Urban Knowledge”, International Journal of Urban and Regional Research, 42, 2, pp. 1140-1151.

HAASE A., RINK D. \& GROSSMANN K. (2016), "Shrinking cities in post-socialist Europe: what can we learn from their analysis for theory building today?", Geografiska Annaler: Series B Human Geography, 98, 4, pp. 305-319.

HAASE A., WOLFF M., ŠPACKOVAP. \& RADZIEMSKI A. (2018), "Reurbanisation in Postsocialist Europe - A Comparative View of Eastern Germany, Poland, and the Czech Republic", Comparative Population Studies, 42, http://urrlab.cz/sites/default/files/295-1089-2-pb.pdf.

Belgeo, 4 | 2018 
HAGEN J., DIENER A.C. (2018), From Socialist to Post-Socialist Cities: Cultural Politics of Architecture, Urban Planning, and Identity in Eurasia, Association for the Study of Nationalities, Routledge.

HIRT S. (2012), Iron Curtains: Gates, Suburbs and Privatization of Space in the Post-Socialist City, Oxford, Wiley.

HIRT S. (2013), “Whatever Happened to the (Post)Socialist City?”, Cities, 32, pp. S29-S38.

HIRT S., FERENČUHOVÁ S. \& TUVIKENE T. (2016), “Conceptual forum: the 'post-socialist' city”, Eurasian Geography and Economics, 57, 4-5, pp. 497-520.

KOVÁCS Z. (2000), “Cities from state-socialism to global capitalism: an introduction”, GeoJournal, 49, 1, Post-socialist urban transition in Eastern and Central Europe, pp. 1-6.

MÜLLER M. (2018), "In Search of the Global East: Thinking between North and South", Geopolitics, https://www.tandfonline.com/doi/full/10.1080/14650045.2018.1477757.

MÜLLER M. (2019), “Goodbye Postsocialism!”, Europe-Asia Studies (in press).

STENNING A., HÖRSCHELMANN K. (2008), "History, Geography, and Difference in Post-Socialist World: Or Do We Still Need Post-Socialism?", Antipode, 40, pp. 313-335.

SÝKORA L., BOUZAROVSKI S. (2012), "Multiple Transformations: Conceptualising the Postcommunist Urban Transition", Urban Studies, 49, pp. 43-60.

TRUBINA E. (2018), "Comparing at What Scale? The Challenge for Comparative Urbanism in Central Asia”, in HORN P. et al. (eds.), Emerging Urban Spaces, pp. 109-127.

TUVIKENE T., SGIBNEV W. \& NEUGEBAUER C.S. (2019), Post-Socialist Urban Infrastructures, Taylor \& Francis/Routledge, UK.

\section{AUTHORS}

\section{MIKHAIL ILCHENKO}

Leibniz Institute for the History and Culture of Eastern Europe (GWZO), Leipzig, Germany; Ural Federal University; Institute of Philosophy and Law (Russian Academy of Sciences, Ural Branch), msilchenko@mail.ru

\section{DIANA DUSHKOVA}

Humboldt University Berlin, Department of Geography; Lomonosov Moscow State University, Department of Geography, kodiana@mail.ru 